\title{
PROMOSI KESEHATAN UNTUK MENINGKATKAN PENGETAHUAN IBU HAMIL DALAM PERILAKU PEMBERIAN ASI EKSKLUSIF DI DESA BANGUN REJO KABUPATEN DELI SERDANG TAHUN 2020
}

\author{
Eva Ratna Dewi ${ }^{1}$, Edy Marjuang Purba ${ }^{2}$, Nur Azizah ${ }^{3}$, Eka Falentina Tarigan $^{4}$ \\ ${ }^{1,3}$ STIKes Mitra Husada Medan Prodi Kebidanan Program Diploma Tiga, Indonesia \\ ${ }^{2,4}$ STIKes Mitra Husada Medan Prodi Kebidanan Program Sarjana, Indonesia \\ ( ${ }^{1}$ evaratna.dewi87@gmail.com, ${ }^{2}$ edymarjuangp@gmail.com, ${ }^{3}$ azizahlubis243@gmail.com, \\ ${ }^{4}$ ekafalentina5@gmail.com )
}

\begin{abstract}
ABSTRAK
Pada tahun 2020, dari jumlah bayi usia kurang dari 6 bulan yang di recall, dari 3.196.303 sasaran bayi kurang dari 6 bulan terdapat 2.113.564 bayi usia kurang dari 6 bulan yang mendapatkan ASI Eksklusif atau sekitar 66,1\%. Capaian indikator persentase bayi usia kurang dari 6 bulan yang mendapatkan ASI Eksklusif sudah memenuhi target tahun 2020, yaitu sebesar 40\% Kurangnya pengetahuan ibu merupakan salah satu faktor internal yang menyebabkan ibu- ibu memberikan susu formula yang tidak sepenuhnya sesuai untuk kesehatan bayi. Tujuan Pengabdian ini adalah untuk Meningkatkan pengetahuan ibu menyusui yang bekerja terhadap pemberian ASI Eksklusif untuk bayi, Meningkatkan perilaku ibu menyusui yang bekerja terhadap pemberian ASI Eksklusif untuk bayi. Kegiatan Pengabdian Masyarakat dilakukan di Desa Bangun Rejo Kecamatan Tanjung Morawa Kabupaten Deli Serdang Provinsi Sumatera dengan jumlah responden 30 ibu Hamil yang trimester III. Setelah diberikan Promosi Kesehatan (penyuluhan) tentang ASI eksklusif ibu-ibu menjadi paham dan mengerti apa itu ASI eksklusif dan manfaatnya bagi ibu dan bayi. Saat diberikan soal setelah penyuluhan sebanyak 56,7\% pengetahuan ibu baik karena ibu menyimak saat diberikan Promosi Kesehatan (penyuluhan) dan adanya rasa ingin tahu dari ibu sendiri. Ini membuktikan sebagai petugas kesehatan perlunya edukasi yang seluas-luas nya kepada masyarakat terutama bagi ibu hamil yang akan memiliki anak dan memberikan ASI Eksklusif. Bagi masayarakat sebaiknya lebih aktif lagi berperan serta dalam pelayanan Kesehatan bagaimana pentingnya pemberian ASI Eksklusifnya dengan baik.
\end{abstract}

Kata Kunci: Promosi Kesehatan, ASI Eksklusif, Pengetahuan

\begin{abstract}
In 2020, from the number of babies aged less than 6 months who were recalled, from 3,196,303 targeted babies less than 6 months, there were 2,113,564 babies aged less than 6 months who received exclusive breastfeeding or around $66.1 \%$. The achievement indicator of the percentage of infants aged less than 6 months who receive exclusive breastfeeding has met the 2020 target, which is $40 \%$. Lack of mother's knowledge is one of the internal factors that causes mothers to give formula milk that is not fully suitable for baby's health. The purpose of this service is to increase the knowledge of breastfeeding mothers who work on exclusive breastfeeding for babies, improve the behavior of breastfeeding mothers who work towards exclusive breastfeeding for babies. Community Service Activities were carried out in Desa Bangun Rejo, Kecamatan Tanjung Morawa, Deli Serdang, Sumatra Utara with a total of 30 pregnant women in the third trimester. After being given Health Promotion (counseling) about exclusive breastfeeding, mothers become aware of what exclusive breastfeeding is and its benefits for mothers and babies. When given questions after counseling as
\end{abstract}


much as $56.7 \%$ of mothers' knowledge was good because mothers listened when given Health Promotion (counseling) and there was curiosity from mothers themselves. This proves as a health worker the need for wide-ranging education to the community, especially for pregnant women who are about to have children and provide exclusive breastfeeding. For the community, it is better to be more active in participating in health services, how important it is to give exclusive breastfeeding properly.

Keywords: Health Promotion, Exclusive Breastfeeding, Knowledge

\section{PENDAHULUAN}

ASI merupakan susu yang tepat untuk bayi karena susu ini khusus diproduksi ibu hanya untuk bayinya. Susu dari ibu memberikan energi yang paling penting untuk bayi. ASI tidak dapat digantikan oleh susu formula yang termahal sekalipun karena zat-zat yang terkadung dalam ASI memiliki suhu yang tepat untuk bayi, mengandung segala zat yang dibutuhkan bayi dan ASI tidak mengandung bakteri yang berbahaya bagi kesehatan bayi ((A.B 2014) Bayi yang mendapatkan ASI memiliki kesehatan dan kepandaian lebih optimal, selain itu ASI juga membuat potensial emosi yang stabil dan memiliki perkembangan sosial yang baik (Roesli 2017).

Menyusui adalah salah satu cara paling efektif untuk memastikan kesehatan dan kelangsungan hidup anak. Namun, hampir 2 dari 3 bayi tidak disusui secara eksklusif selama 6 bulan yang direkomendasikan - angka yang tidak membaik dalam 2 dekade. ASI adalah makanan yang ideal untuk bayi. Aman, bersih dan mengandung antibodi yang membantu melindungi dari banyak penyakit umum pada masa kanak-kanak. ASI menyediakan semua energi dan nutrisi yang dibutuhkan bayi untuk bulan-bulan pertama kehidupan, dan terus menyediakan hingga setengah atau lebih dari kebutuhan nutrisi anak selama paruh kedua tahun pertama, dan hingga sepertiga selama paruh kedua tahun kedua. tahun kehidupan. Bayi yang disusui memiliki kinerja yang lebih baik dalam tes kecerdasan, cenderung tidak kelebihan berat badan atau obesitas dan kurang rentan terhadap diabetes di kemudian hari(Nurhastuti 2019)merekomendasikan agar anak-anak mulai menyusui dalam satu jam pertama kelahiran dan disusui secara eksklusif selama 6 bulan pertama kehidupan - artinya tidak ada makanan atau cairan lain yang disediakan, termasuk air. Bayi harus disusui sesuai permintaan - sesering yang diinginkan anak, siang dan malam. Botol, dot, atau dot tidak boleh digunakan. Sejak usia 6 bulan, anak-anak harus mulai makan makanan pendamping yang aman dan memadai sambil terus menyusui hingga 2 tahun dan seterusnya.WHO secara aktif mempromosikan ASI sebagai sumber nutrisi terbaik untuk bayi dan anak kecil, dan berupaya meningkatkan angka pemberian ASI eksklusif untuk 6 bulan pertama hingga setidaknya 50\% pada tahun 2025 (Nurhastuti 2019).

Menurut data (Kemenkes RI 2018),proporsi waktu mulai menyusui pada bayi pada usia 0-5 Bulan kurang dari 1 jam sebesar 14,98\%, 1-6 jam sebesar 30,48\%, 7-23 Jam sebesar 9,15\%, 24-47 jam sebesar 10,59\%, >48 jam sebesar 34,79\%. Proporsi ini berbeda antara bayi jenis kelamin perempuan dan laki-laki, dilihat dari angka proporsinya lebih sering menyusu bayi jenis kelamin perempuan dibandingkan bayi kenis kelamin laki-laki. 
Bayi dengan ASI Ekslusif akan memiliki daya tahan tubuh yang lebih kuat dibandingkan dengan bayi yang diberikan susu formula (Maryunani 2016). ASI memberikan perlindungan kepada bayi terhadap berbagai penyakit terutama penyakit akibat infeksi.Menurut WHO, setiap tahun 1-1,5 juta bayi di dunia meninggal karena tidak diberi ASI secara Ekslusif (Roesli, 2015). Pedoman Internasional yang mengajukan pemberian ASI Eklusif selama 6 bulan pertama didasarkan pada bukti ilmiah tentang manfaat ASI Ekslusif bagi daya tahan hidup bayi (Wahyuni, 2012).

Pada tahun 2020, dari jumlah bayi usia kurang dari 6 bulan yang di recall, dari 3.196.303 sasaran bayi kurang dari 6 bulan terdapat 2.113.564 bayi usia kurang dari 6 bulan yang mendapatkan ASI Eksklusif atau sekitar 66,1\%. Capaian indikator persentase bayi usia kurang dari 6 bulan yang mendapatkan ASI Eksklusif sudah memenuhi target tahun 2020, yaitu sebesar $40 \%$. Berdasarkan distribusi provinsi, sebanyak 32 provinsi telah mencapai target yang diharapkan dan masih terdapat 2 provinsi yang tidak mencapai target, yaitu Papua Barat (34\%) dan Maluku (37,2\%), sementara provinsi dengan capaian tertinggi adalah Nusa Tenggara Barat (87,3\%) (Kemenkes RI, 2021)

Kurangnya pengetahuan ibu merupakan salah satu faktor internal yang menyebabkan ibu- ibu memberikan susu formula yang tidak sepenuhnya sesuai untuk kesehatan bayi. Rendahnya pengetahuan ini dapat disebabkan karena ibu belum pernah mendapatkan informasi tentang manfaat ASI atau ibu hanya sebatas mendengar namun tidak bisa melaksanakan ASI Ekslusif. Pengetahuan ibu yang rendah, berdampak terhadap sikap ibu yang kemudian akan berpengaruh terhadap perilaku ibu dalam pemberian ASI. Ibu menyusui yang bekerja juga berpengaruh terhadap penurunan pemberian ASI secara Ekslusif.Kesibukan ibu bekerja kantoran atau bekerja di luar rumah membuat ibu tidak sempat memberikan ASI kepada bayinya. Pengetahuan dan ketrampilan ibu dalam pemberian ASI secara Eksklusif sangat penting dalam mendukung pemberian ASI secara Ekslusif. Meskipin ibu bekerja bayi tetap minum susu ibu yang sudah diperas dan dimasukkan dalam botol dan disimpan dalam fliser atau kulkas. Pencapaian ASI Eksklusif di Desa Bangun Rejo masih rendah yaitu sebesar 63,46\% dibandingkan kota lain. Rendahnya pencapaian ASI Ekslusif di Desa Bangun Rejo sangat dipengaruhi oleh kondisi ibu yang bekerja diluar rumah atau bekerja kantoran yang membuat tidak bisa menyusui bayinya. Disamping itu pengetahuan ibu terhadap ASI Ekslusif masih kurang memahami penting dan manfaat ASI Ekslusif. Kurangnya pengetahuan ibu dan ketrampilan ibu dalam membuat ASIP (Air Susu Ibu yang Peras) menghambat pemberian ASI secara Ekslusif kepada bayi. Kekurang pahaman ibu dan kesibukan ibu bekerja membuat ibu lebih memilih susu formula yang lebih praktis untuk bayi. Berdasarkan hal tersebut maka perlu dilakukan pengabdian masyarakat dalam upaya promosi kesehatan untuk meningkatkan pengetahuan ibu hamil trimester III dalam perilaku pemberian ASI eksklusif .Tujuan Pengabdian ini adalah untuk Meningkatkan pengetahuan ibu menyusui yang bekerja terhadap pemberian ASI Eksklusif untuk bayi, Meningkatkan perilaku ibu menyusui yang bekerja terhadap pemberian ASI Eksklusif untuk bayi. 


\section{METODE}

Metode kegiatan pengabdian ini adalah Penyuluhan dengan kelompok pre-test dan post-test. Kegiatan Pengabdian Masyarakat dilakukan di Desa Bangun Rejo Kecamatan Tanjung Morawa Kabupaten Deli Serdang Provinsi Sumatera dengan jumlah responden 30 ibu Hamil yang trimester III. Evaluasi kegiatan pengabdian masyarakat ini menggunakan metode pretest dan posttest. Para ibu diberikan soal pretest sebelum dilakukannya Promosi Kesehatan (Penyuluhan), setelah Promosi Kesehatan (Penyuluhan) para ibu diberikan soal yang sama dengan soal pretest. Lalu, dinilai pengetahuan ibu sebelum dan sesudah diberikan Promosi Kesehatan (Penyuluhan). Alat bantu saat penyuluhan yaitu leafleat tentang ASI eksklusif. Bentuk soal yang diberikan yaitu soal pilihan ganda tentang ASI.

\section{HASIL DAN PEMBAHASAN}

Hasil kegiatan pengabdian pada Ibu Hamil Trimester III di Desa Bangun Rejo Kabupaten Deli Serdang adalah sebagai berikut: Pemberian materi tentang Promosi Kesehatan Meningkatkan Pengetahuan Ibu Hamil Dalam Perilaku Pemberian ASI Eksklusif Di Desa Bangun Rejo Kabupaten Deli Serdang Tahun 2020. Pengabdian ini dilakukan di Desa Bangun Rejo, Pada kegiatan ini dihadiri oleh bidan Desa dan ketua pelaksana pengabdian, kader dan 30 Responden ibu hamil TM III dan TIM Pengabdian UPPM STIKes Mitra Husada Medan. Adapun nilai pre test pengetahuan sebelum dan sesudah pemberian materi sebagai berikut:

Tabel 1. Pengetahuan Ibu Hamil TM III dalam perilaku Pemeberian ASI eksklusif

\begin{tabular}{llcccc}
\hline \multirow{2}{*}{ No } & \multirow{2}{*}{ Pengetahuan } & \multicolumn{2}{c}{ Pre-Test } & \multicolumn{2}{c}{ Post- Test } \\
\cline { 3 - 6 } & & $\mathbf{N}$ & $\mathbf{\%}$ & $\mathbf{N}$ & $\mathbf{\%}$ \\
\hline 1. & Baik & 11 & 36.7 & 17 & 56.7 \\
2. & Cukup & 16 & 53.3 & 13 & 43.3 \\
3. & Kurang & 3 & 10 & 0 & 0 \\
\hline 3. & Jumlah & 30 & 100 & 30 & 100 \\
\hline
\end{tabular}

Dari tabel 1 didapatkan hasil pengetahun ibu saat dilakukan prestest sebelum Promosi Kesehatan (penyuluhan) yaitu pengetahuan ibu yang baik ada $11 \mathrm{ibu}(36,7 \%)$ dan pengetahuan ibu yang cukup ada 16 ibu $(53,3 \%)$, Serta Pengetahuan Ibu yang Kurang ada 3 ibu (10\%). hasil ini menunjukkan bahwa pengetahuan ibu tentang ASI masih kurang. Setelah diberikan Promosi Kesehatan (penyuluhan) hasil yang didapatkan yaitu pengetahui ibu yang baik ada $17 \mathrm{ibu}(56,7 \%)$ dan pengetahuan ibu yang cukup ada $13 \mathrm{ibu}(43.3 \%)$ Sehingga dapat disimpulkan, pengetahuan ibu tentang ASI eksklusif meningkat setelah diberikan penyuluhan. 


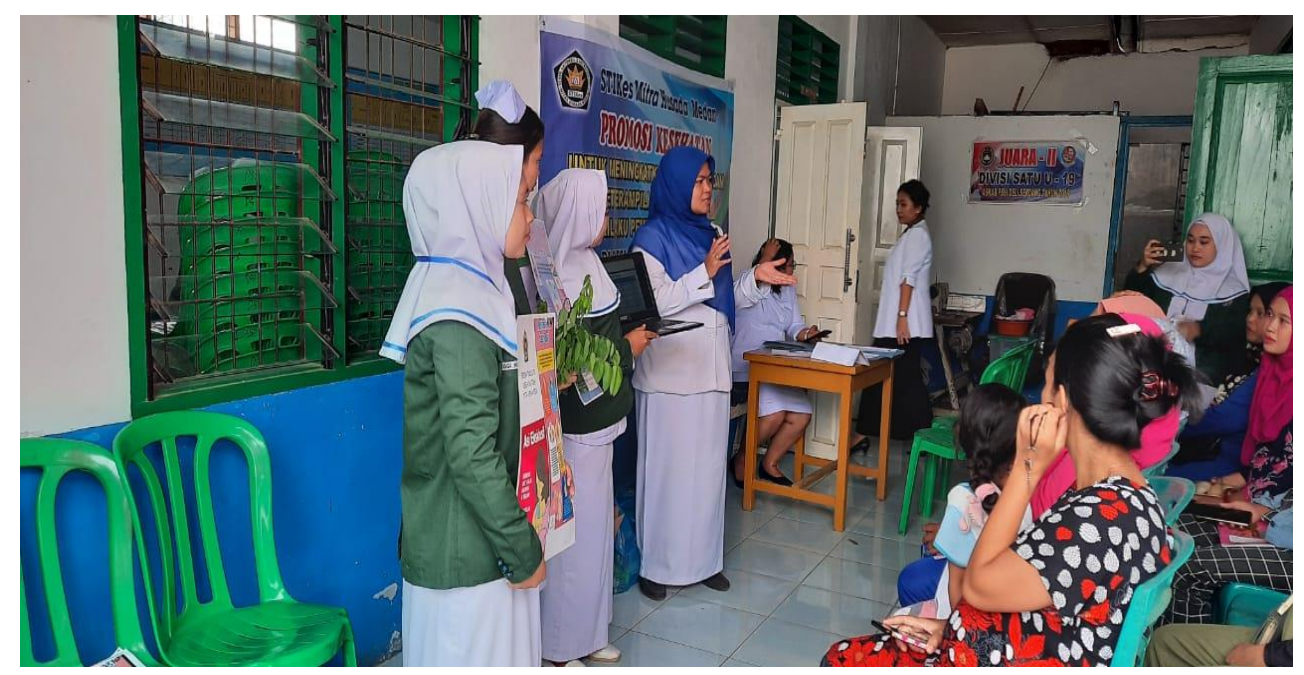

Gambar 1. Dokumentasi kegiatan pengabdian kepada masyarakat

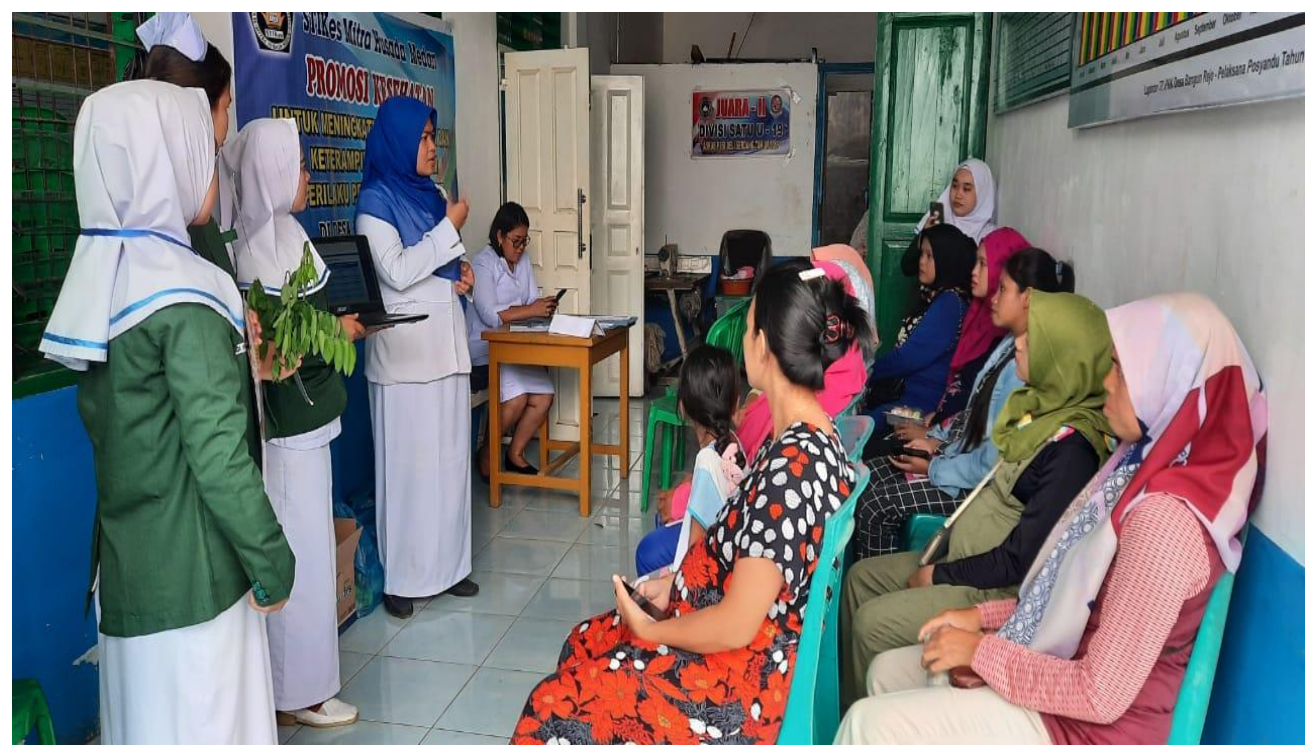

Gambar 2. Kegiatan Memberikan Materi Promosi Kesehatan terkait dengan pemberian ASI eksklusif dan perrilaku ibu dalam memberikan ASI eksklusif

\section{KESIMPULAN}

Setiap Ibu hamil hampir rata-rata ibu hamil trimester III sebelum diberikan promosi kesehatan (Penyuluhan) tentang Perilaku Pemberian ASI Eksklusif tidak menyusui sampai 
6 bulan pada anak sebelumnya, alasannya krn ASI tidak lancar, Ibu bekerja. dengan alasan air susu yang tidak lancar pengeluarannya dan pada ibu yang bekerja juga tidak bisa memberikan ASI eksklusif secara maksimal Setelah diberikan Promosi Kesehatan (penyuluhan) tentang ASI eksklusif ibu-ibu menjadi paham dan mengerti apa itu ASI eksklusif dan manfaatnya bagi ibu dan bayi. Saat diberikan soal setelah penyuluhan sebanyak 56,7\% pengetahuan ibu baik karena ibu menyimak saat diberikan Promosi Kesehatan (penyuluhan) dan adanya rasa ingin tahu dari ibu sendiri . Ini membuktikan sebagai petugas kesehatan perlunya edukasi yang seluas-luas nya kepada masyarakat terutama bagi ibu hamil yang akan memiliki anak dan memberikan ASI Eksklusif. Bagi masayarakat sebaiknya lebih aktif lagi berperan serta dalam pelayanan Kesehatan bagaimana pentingnya pemberian ASI Eksklusifnya dengan baik.

\section{UCAPAN TERIMA KASIH}

Pengabdian kepada masyarakat yang dilakukan oleh penulis tidak terlepas dari banyak operan yang mendukung, penulis mengucapkan terima kasih kepada pihak-pihak yang terkait dalam kegiatan ini. Terima kasih kepada kepal desa bangung rejo yang telah memberikan izin kepada penulis untuk melaksanakan kegiatan pengabdian di desa tersebut. Terima kasih juga kepada bidan desa dan kader yang sudah banyak membantyu penulis untuk kegiatan pengabdian ini. Terima kasih kepada Bapak Drs. Imran saputra Surbakti., MM sebagai Ketua Pengurus Yayasan Mitra Husada Medan yang telah memfasilitasi penulis hingga kegiatan ini dapat terlaksana dengan lancar. Terima kasih kepada ibu Dr.Siti

Nurmawan Sinaga., SKM., M.Kes sealku Ketua STIKes Mitra Husada Medan Yang terus memberikan motivasi kepada penulis untuk melaksanakan kegiatan ini. Terima kasih kepada UPPM STIKes Mitra Husada Medan yang sudah membantu penulis agar kegiatan ini dapat dilaksanakan dengan baik.

\section{REFERENSI}

A.B, Nirwana. 2014. ASI Dan Susu Formula Kandungan Dan Manfaat ASI Dan Susu Formula. Yogyakarta: Nuha Medika.

Kemenkes RI. 2018. "Hasil Riset Kesehatan Dasar Tahun 2018.” Kementrian Kesehatan RI 53(9):1689-99.

Kementerian Kesehatan Republik Indonesia. 2021. "Kementerian Kesehatan Tahun 2011 Kementerian Kesehatan.” Laporan Akuntabilitas Kinerja Tahun 2020.

Maryunani, Anik. 2016. Asuhan Keperawatan Maternitas. Jakarta: Rineka Cipta.

Nurhastuti. 2019. "World Health Statistics Overview 2019."

Roesli. 2017. Mengenal ASI Eksklusif. Jakarta: Trubus Agriwidya. 